\title{
並立する柔軟構造物の曲げねじれ振動制御*
}

$$
\begin{aligned}
& \text { 松本幸 人*1, 福 田 雄 } \text { 一*2 }^{* 2} \\
& \text { 土井文 夫*1, 背 戸 一 }
\end{aligned}
$$

\section{Bending and Torsional Vibration Control for Flexible Structures arranged in Parallel}

\author{
Yukito MATSUMOTO, Yuichi FUKUDA, \\ Fumio DOI and Kazuto SETO
}

\begin{abstract}
This paper deals with a bending and torsional vibration control method for flexible structures arranged in parallel, and a method for making a multi degree- of-freedom model by using uncontrollability and unobservability. According to these methods, it is easy to make reduced-order-models of flexible structures, and a pair of flexible structure are controlled actively by controlling each other by means of actuators placed between them. Therefore it is able to obtain enough control force under the low frequency, and control vibration of the super tall building by the strong wind. In this paper, two real structures are reduced to $4 \mathrm{DOF}$ models respectively including bending and torsional modes for controlling the bending and torsional vibration. These models are evaluated by means of comparing the simulated frequency response with the measured one using real structures. The effectiveness of these methods is demonstrated by the vibration control using LQ and semioptimal control theory theoretically and experimentally.
\end{abstract}

Key Words: Torsional Vibration, Vibration Control, Flexible Structure, Modeling, LQ Control Theory, Spillover

\section{1. 緒}

現在，高層ビルに用いられている制振装置は動吸振 器が主流となっている。しかし，阪神大震災ではその 効果を十分発揮できずに終わり，またさらに高層ビル が高層化していった場合，十分に制御力が得られなく なることが指摘されており，これに代わる新しい制振 法が望まれている。そこで著者らは新しい振動制御手 法として, 複数の構造物が並立する場合に各構造物間 にアクチュエータを配置して, 各構造物の相互作用に より振動を制御するビル連結方式という方法を提案 し(1)(図 1 参照)，この方法の実現に向けて研究を重ね てきた。

一方，制御系設計では LQ 制御理論を用いることが 多いが, 適切な低次元化モデル作成法が存在しないた め, しばしばスピルオーバと呼ばれる不安定振動の発 生が問題となる。そこで著者らは，スピルオーバ防止 を目的とした「不可制御・不可観測性を活用した低次

* 原稿受付 1997 年 4 月 28 日.

*1. 正員, 協和合金 (株) 振動制御研究所 (恶 236-0004 穔浜市金 沢区福浦 $1-7-2)$.

*2 日本大学大学院（㤲 101-8308 東京都干代田区神田駿河台 I $-8)$.

*3 正員, 日本大学理工学部。
元化モデル作成法」を提案している ${ }^{(2)}$.

本報では，二つの構造物の曲げとねじれそれそれの 一次と二次のモードを制御対象とし，各構造物に対し て曲げとねじれを考慮した四自由度の低次元化モデル を作成し，笑際の構造物とモデルの周波数応答を比較 することによって，提案するモデル作成法が構造物の 曲げとねじれの振動を制御するための低次元化モデル を作る場合にも有効であることを実証している。ま たこれまでのように構造物の曲げ振動だけでなく， ねじれ拢動を考慮することにより構造物の固有振動数 が接近するため，前述の不可制御，不可観測性を活用 したスピルオーバ防止法だけでは不十分である.そこ

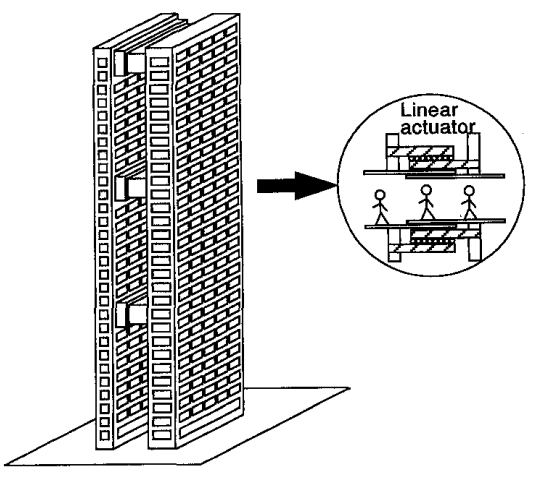

Fig. 1 Actively connected method between buildings 
でローパスフィルタを導入し，制御系の状態方程式を 拡張して最適のフィードバックコントローラを決定す る「フィルタ包含 $\mathrm{LQ}$ 制御」(3) 併せて適用している。 一方，同時に八つもの振動モードを制御するために制 御系の次数の増大が懸念される。そこで, 構造制約の ある場合の解法として知られる「準最適制御理論 (4) を導入して, 制御系の次数を縮小して制御を行ってい る、これらの手法を併用してシミュレーションと制御 実験を行い，提案する振動制御法の有効性を検泟した ので報告する。

\section{2. 構造物の低次元化モデル作成}

$2 \cdot 1$ 低次元化モデル作成法本研究で研究対象 とする並列構造物は，図２に示すように厚さの違う二 つの板状構造物が二つのアクチュエータで連結された 構造になっている. 以後, 左側の厚いほうを構造物 1 , 在側の薄いほうを構造物 2 とする。このような分布定 数系の構造物に対して最適制御理論を適用して制御を 行う場合，制御対象の振動モードだけを適切に表現す る物理モデルに低次元化する必要がある。そこで，二 つの構造物の曲げとねじれそれぞれの一次と二次の振 動モードを制御対象と決め, 各構造物に対して制御対 象の四つの振動モードのみをもつ四自由度の低次元化

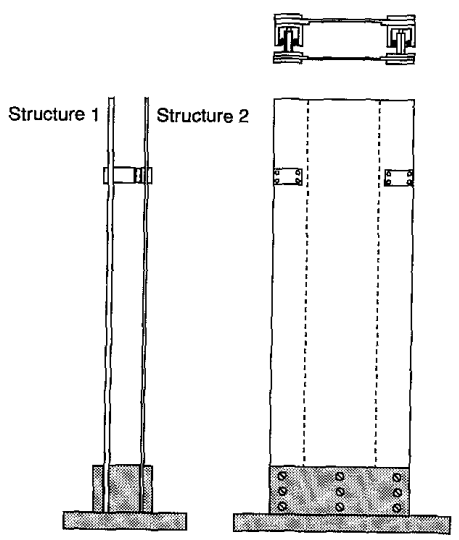

Fig. 2 Schematic view of flexible structures arranged in parallel

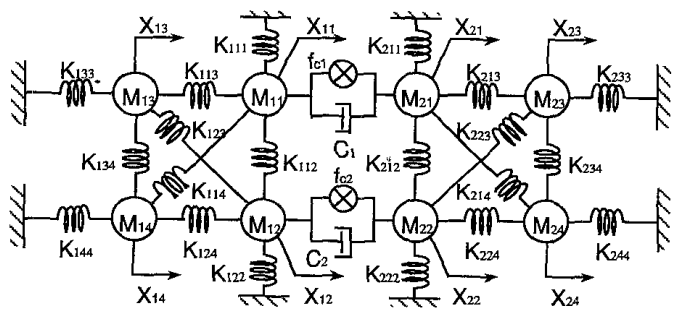

Fig. 3 Reduced-order physical model of these structures
モデルを作成し，それらをアクチュエータと減衰要素 で連結することで並列構造物全体の低次元化モデルを 構成する。これを図で表わしたものが図 3 である。こ こに $M_{i j}$ と $x_{i j}$ は各構造物を四質点系で表した場合の 質点とその変位， $K_{i j s}$ は各質点間を結合するばねのば ね定数である。ただし， $i$ は構造物 1,2 を表し $j, s$ は 各構造物の質点番号を表す。この $M_{i j}, K_{i j s}$ を決定す る方法を以下に述べる. なお，低次元化モデルの質点 の位置，およびモデルパラメー夕を同定する方法とし て,「不可制御・不可観測性を活用した低次元化モデ ル作成法」を用いる。この方法の詳細については文献 （2）を参照されたい.ここでは本研究における適用方 法を簡単に述べる。

まず，図 4 に有限要素法のはん用ソフトウェアであ るANSYSを用いて求めた構造物の一次から七次ま での振動モード形を示す。ただし，各構造物の形状は 厚みが違うだけで類似しており，同様の振動モード形 になることがわかっているのでここでは構造物 1 の振 動モード形のみ宗す。一次モードが曲げ一次, 二次 モードがねじれ一次，三次モードが曲げ二次，四次モ ードがねじれ二次に相当する。
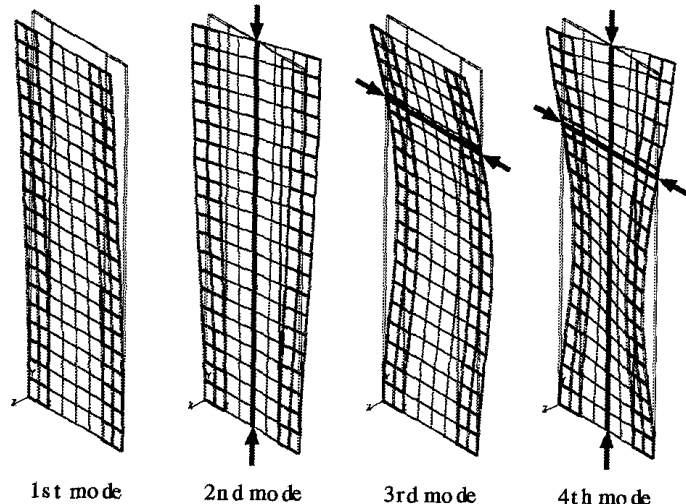

1 st mode $4.5 \mathrm{~Hz}$

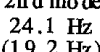

3 rd mode $3 \mathrm{rd} \bmod$
$29.1 \mathrm{~Hz}$ 4 th mode $24.1 \mathrm{~Hz}$

$\begin{array}{ll}(21.5 \mathrm{~Hz}) & (53.5 \mathrm{~Hz})\end{array}$
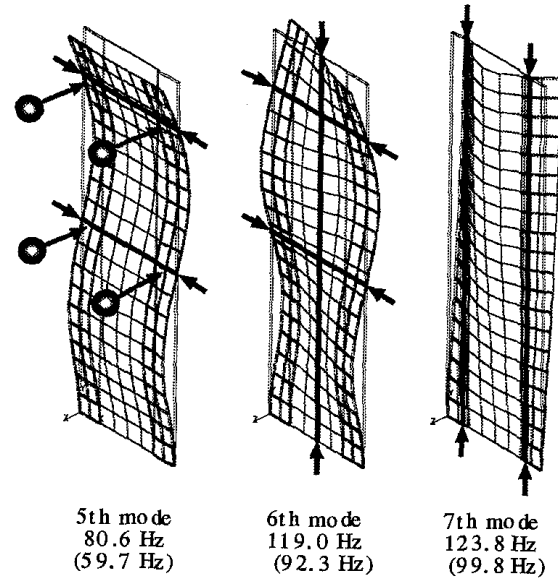

5 th $80.6 \mathrm{~Hz}$ $(59.7 \mathrm{~Hz})$

$6 \mathrm{th}$ mode

$119.0 \mathrm{~Hz}$
$(92.3 \mathrm{~Hz})$

Fig. 4 Vibration mode shapes and corresponding natural frequencies of the structures 
ここで，モデリングに扔いて除外される高次モード のうち最低次のモード，この場合は五次モードの節上 に低次元化モデルの四つの質点を設定する．この位置 では五次モードのモード振幅が零のため制卸力によっ て励振されることがなく，五次モードが不可制御とな りスピルオーバの発生を回避することができる.同様 に，六次モードの節上にセンサを設置すれば六次モー ドが不可観測となり六次モードのスピルオーバを防ぐ ことができる。ただし今回の場合は七次モードの節が 図 4 に示すように六次モードの節と交差しており，こ れらの交点にセンサを設置することで六次と七次のモ ードが同時に不可観測となり，六次と七次のモードの 観測スピルオーバを防ぐことができる.

次に, 各質点に扔ける一次から四次の固有モード成 分を行列の成分に持つ固有モード行列に対して，モー ド質量行列が単位行列になるように正規化したものを 正規化固有モード行列 $\boldsymbol{\Phi}$ とし, 固有振動数を対角要 素とする周波数行列を $\Omega$ とおくと，質量行列 $\boldsymbol{M}$, 剛 性行列 $\boldsymbol{K}$ は以下のようになる。

$$
\begin{aligned}
& \boldsymbol{M}=\left(\boldsymbol{\Phi} \boldsymbol{\Phi}^{T}\right)^{-1} \\
& \boldsymbol{K}=\left(\boldsymbol{\Phi}^{T}\right)^{-1} \boldsymbol{\Omega}^{2} \boldsymbol{\Phi}^{-1}
\end{aligned}
$$

ここで, 集中定数系の条件を満たすように, 誤差関 数 $\varepsilon$ を定義し，これを零にするような正規化固有モ一 ド行列 $\Phi$ の修正を行う。 $\Phi$ に対する誤差関数の感度 行列を $[\partial \boldsymbol{\varepsilon} / \partial \boldsymbol{\Phi}]$, 修正量を $\delta \boldsymbol{\Phi}$ とすると, 誤差関数 $\boldsymbol{\varepsilon}$ を零とする修正量は次式で求められる。

$$
\delta \boldsymbol{\Phi}=\left[\frac{\partial \boldsymbol{\varepsilon}}{\partial \boldsymbol{\Phi}}\right]^{T}\left(\left[\frac{\partial \boldsymbol{\varepsilon}}{\partial \boldsymbol{\Phi}}\right]\left[\frac{\partial \boldsymbol{\varepsilon}}{\partial \boldsymbol{\Phi}}\right]^{T}\right)^{-1}(-\boldsymbol{\varepsilon})
$$

この修正量を用いて誤差関数を零に収束させれば集中 定数系の条件を満足する固有モード行列が得られる。 こうして得た固有モードを式(1)，(2)に代入して， 質量行列 $M$, 岡性行列 $K$ 救めることにより低次元 化モデルのパラメータが得られる。

このようにして求められた各構造物の低次元モデル

Table 1 Parameters of reduced-order-model

\begin{tabular}{|c|l|l|}
\hline & \multicolumn{1}{|c|}{ Structure 1 } & \multicolumn{1}{c|}{ Structure 2 } \\
\hline Mass [kg] & $M_{11}=M_{12}=1.35$ & $M_{21}=M_{22}=0.90$ \\
& $M_{13}=M_{14}=1.66$ & $M_{23}=M_{24}=1.02$ \\
\hline & $K_{111}=K_{122}=-9858$ & $K_{211}=K_{222}=-3431$ \\
& $K_{112}=41793$ & $K_{212}=17935$ \\
Stiffness & $K_{113}=K_{124}=62610$ & $K_{213}=K_{224}=25104$ \\
{$[\mathrm{~N} / \mathrm{m}]$} & $K_{114}=K_{123}=-44542$ & $K_{214}=K_{223}=-18484$ \\
& $K_{133}=K_{144}=29098$ & $K_{233}=K_{244}=9686$ \\
& $K_{134}=90149$ & $K_{234}=36431$ \\
\hline Damping & \multicolumn{2}{|c|}{$C_{1}=3.3, C_{2}=3.6$} \\
{$[\mathrm{Ns} / \mathrm{m}]$} & \multicolumn{2}{|c}{} \\
\hline
\end{tabular}

のモデルパラメータを表 1 に示す.

$2 \cdot 2$ 低次元化モデルの検討 $2 \cdot 1$ 節で作成され た低次元化モデルが, 制御対象の振動モードを正確に 表しているかどうか, 実機と低次元化モデルの周波数 応答を比較することにより検討を行う。図 5 に各構造 物の実機と低次元化モデルの周波数応答を示す. 図 5 (a) 注構造物 1 の質点 11 を加振し, 構造物 1 の各点

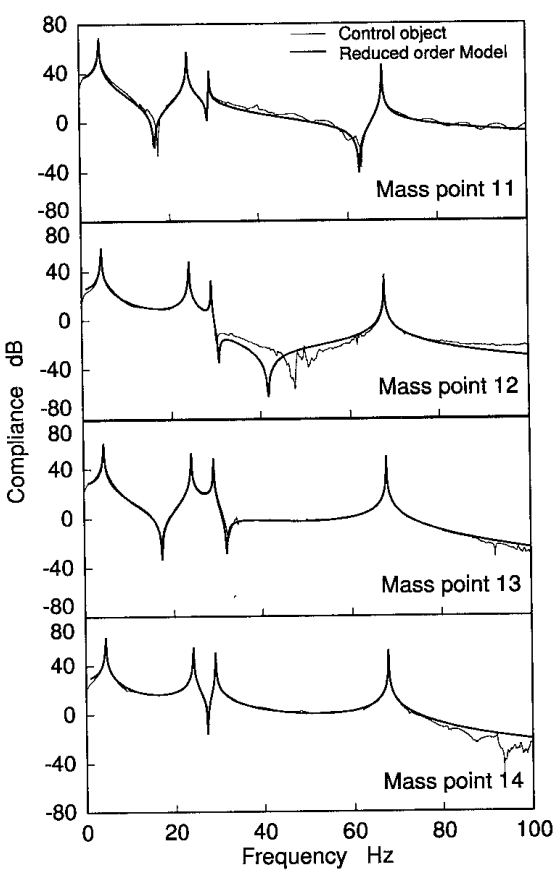

(a) Structure 1

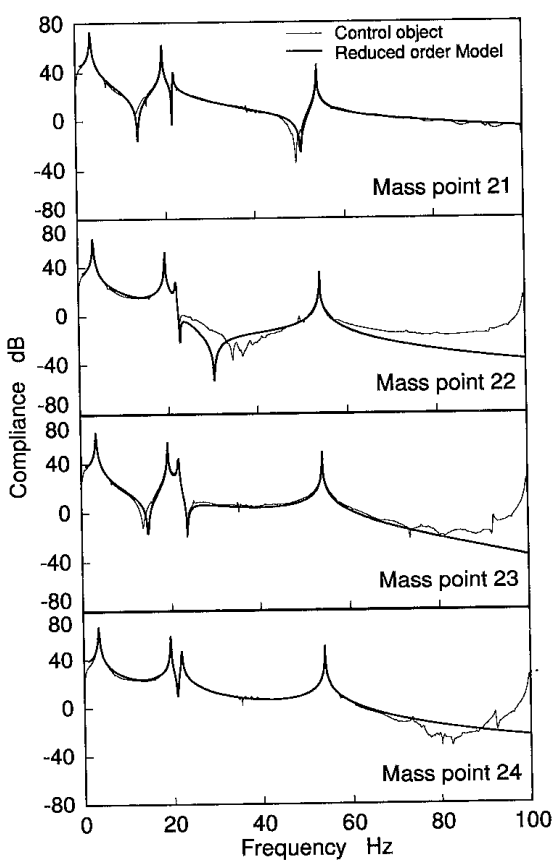

(b) Structure 2

Fig. 5 Comparis on between reduced-order-model and real structure by frequency response 
で観測したとき，図 5(b) は構造物 2 の質点 21 を加振 し, 構造物 2 の各点で観測したときの応答を示してい る.

図 5 に示すように，各構造物ともに一次と四次まで の固有振動数が一致しており，かつ各構造物の各質点 での応答において共振, 反共振の位置関係も一致して いる. 一方, 構造物 1 の質点 11,14 や, 構造物 2 の質 点 $22,23,24$ での応答を見ると $80 \mathrm{~Hz}$ 以降では実機 とモデルの応答がずれていることが確認されるが，こ れはモデル化において無視された実機の五次のピーク が現れていることが原因である.これらの結果から考 えて, 各構造物に対して五次以降の振動モードを無視 したにもかかわらず曲げとねじれを含む一次から四次 までの振動モードが高い精度でモデルに表されている ことがわかり，作成した低次元化モデルが制御系設計 に用いるのに十分な信頼性を有しているといえる.

\section{3. 制 御 系 設計}

\section{$3 \cdot 1$ フィルタを含む拡張系の状態方程式表示} 分布定数系の構造物を最適制御理論を適用して制御す る場合，低次元化モデルを作成する必要があるが，そ の際に無視した高次モードによるスピルオーバ防止を 目的として「不可制御，不可観測性を活用した低次元 化モデル作成法」を用いていることはすでに述べてい る.しかし，この手法で考慮できる高次モードは基本 的に二つまでであり，ねじれモードを制御対象として 考慮した場合, 構造物の各固有振動数が接近すること になり，さらに高次のモードによるスピルオーバの発 生が予想され，それらへの対策が必要となる。そこで ローパスフィルタを導入し，フィルタを含む拡張系の 状態方程式に対して LQ 制御理論を適用し, 制御系設 計を行う。これら二つの手法を組合わせて用いること により、ローパスフィルタのみを使用する場合よりも フィルタのカットオフ周波数を高くすることができ, 制御対象モードに対する制御效果の低下を軽減するこ とができる。

制御量 $\boldsymbol{U}$ をローパスフィルタを通して出力すれば, フィルタの状態方程式と出力方程式は次のように表さ れる。

$$
\begin{aligned}
\dot{\boldsymbol{X}}_{f} & =\boldsymbol{A}_{f} \boldsymbol{X}_{f}+\boldsymbol{B}_{f} \boldsymbol{U}_{f} \\
\boldsymbol{Y}_{f} & =\boldsymbol{C}_{f} \boldsymbol{X}_{f} \cdots \ldots \ldots \ldots
\end{aligned}
$$

制御対象についても同様に次式で表される.

$$
\dot{\boldsymbol{X}}_{s}=\boldsymbol{A}_{s} \boldsymbol{X}_{s}+\boldsymbol{B}_{s} \boldsymbol{U}_{s}
$$$$
Y_{S}=C_{S} X_{S}
$$

ここで, フィルタの出力が制御詨象の入力であるか 5

$$
Y_{f}=U_{s}
$$

したがってフィルタを含めた制御系の状態方程式およ び出力方程式は，このように表される。

$$
\begin{aligned}
& \dot{X}=\boldsymbol{A} \boldsymbol{X}+\boldsymbol{B} \boldsymbol{U} \\
& \boldsymbol{Y}=\boldsymbol{C} \boldsymbol{X} \cdots \ldots
\end{aligned}
$$

ここに,

$$
A=\left[\begin{array}{cc}
A_{f} & O \\
B_{s} C_{f} & A_{s}
\end{array}\right], B=\left[\begin{array}{c}
B_{f} \\
O
\end{array}\right], C=\left[\begin{array}{cc}
C_{f} & O \\
O & C_{s}
\end{array}\right]
$$

$3 \cdot 2 \mathrm{LQ}$ 制御理論 以上で示した状態方程式に $\mathrm{LQ}$ 制御理論を適用し最適なフィードバックコントロ ーラを決定する。設計パラメータは，次に示す線形二 次形式の評洒関数 $J$ に与える重み係数行列 $\boldsymbol{Q}, \boldsymbol{R}$ であ る.ただし， $\boldsymbol{Q}$ は状態べクトル $\boldsymbol{X}$ に, $\boldsymbol{R}$ は制御量 $\boldsymbol{U}$ に掛かる重み係数行列である。

$$
J=\int_{0}^{\infty}\left(\boldsymbol{X}^{T} \boldsymbol{Q} \boldsymbol{X}+\boldsymbol{U}^{T} \boldsymbol{R} \boldsymbol{U}\right) d t
$$

LQ 制御理論に基づけば，この評価関数 $J$ を最小にす る制御量 $\boldsymbol{U}$ は次のように定式化されており,リカッ チ方程式を解くことによりフィードバックゲイン $\boldsymbol{K}$ を決定することができる。

$$
U=-R^{-1} B^{T} P X=-K X
$$

ここに, $P$ は次のリカッチ方程式の解である.

$$
\boldsymbol{P A}+\boldsymbol{A}^{T} \boldsymbol{P}-\boldsymbol{P B R ^ { - 1 } B ^ { T } P + Q = 0}
$$

$3 \cdot 3$ 準最適制御理論本研究では曲げとねじれ を含めた八つのモードを制御対象としており，それに 伴い制御系の次数が大きくなってしまうのが難点であ る.そこで構造制約がある場合の解法として知られる 準最適制御理論を導入し，意図的にフィードバックす る状態量の数を減らし，制御系の次数を縮小する.

最小ノルム解を用いた準最適制御問題は次のように 定式化されている。すなわち測定できない状態量を除 いた状態ベクトルを $Z$ とし, 構造制約行列を $S$ とし

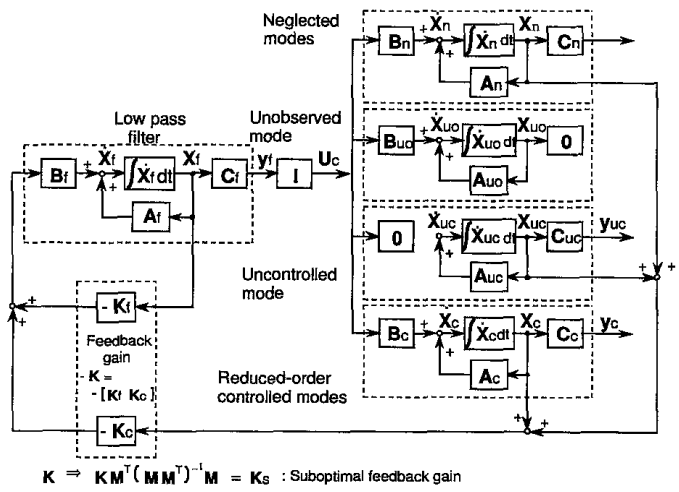

Fig. 6 Block diagram representation of controlled and uncontrolled systems 
て次のような線形変換を行う.

$$
Z=S X
$$

本研究では状態量は次に示すように 20 個存在する.

$$
\begin{aligned}
\boldsymbol{X}= & \left\{\dot{x}_{f 1} \dot{x}_{f 2} x_{f 1} x_{f 2} \dot{x}_{11} \dot{x}_{12} \dot{x}_{13} \dot{x}_{14} \dot{x}_{21} \dot{x}_{22} \dot{x}_{23}\right. \\
& \left.\dot{x}_{24} x_{11} x_{12} x_{13} x_{14} x_{21} x_{22} x_{23} x_{24}\right\}^{T} \ldots \ldots \ldots \ldots \ldots .
\end{aligned}
$$

ここで, 左の 4 個はフィルタに関する状態量, 残りが

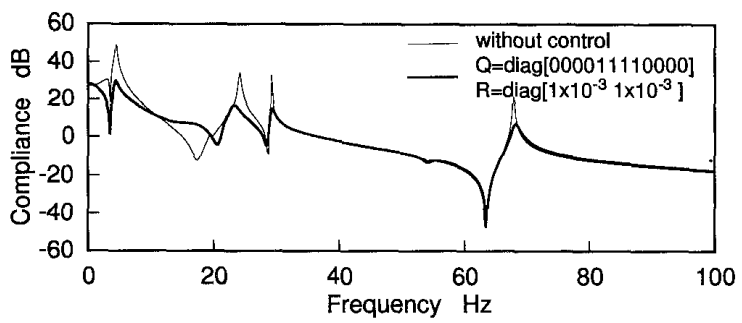

(a) Structure 1

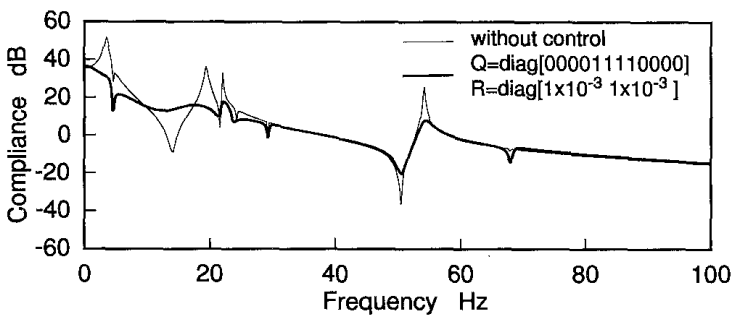

(b) Structure 2

Fig. 7 Simulated frequency response

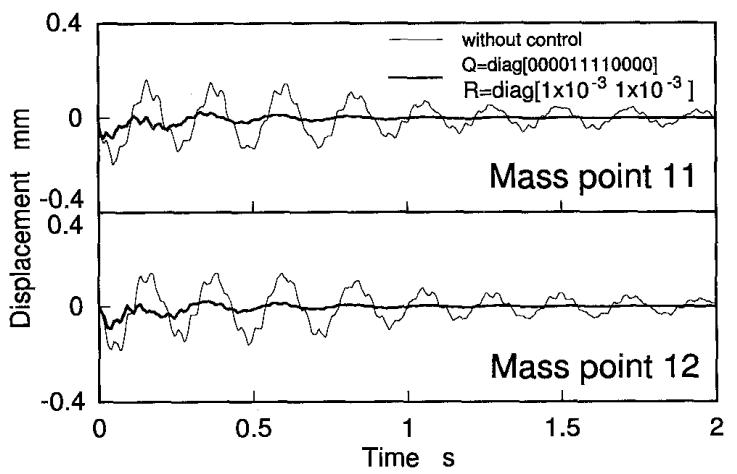

(a) Structure 1

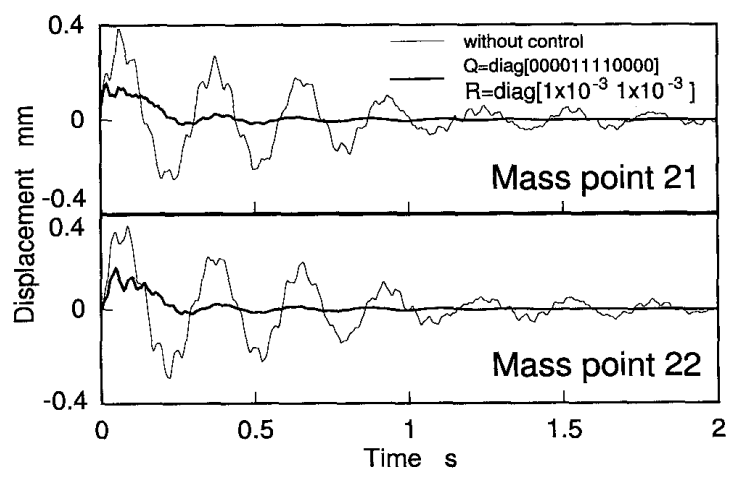

(b) Structure 2

Fig. 8 Simulated impulse response
構造物の各質点の速度と変位である.この状態べクト ルを式(15)により次のように変換する。

$$
Z=\left\{\dot{x}_{f 1} \dot{x}_{f 2} x_{f 1} x_{f 2} \dot{x}_{11} \dot{x}_{12} \dot{x}_{21} \dot{x}_{22} x_{11} x_{12} x_{21} x_{22}\right\}^{T}
$$

この状態ベクトル $Z$ でフィードバックを構成する と,

$$
U=-K_{s} Z
$$

ここに準最適フィードバックゲイン $\boldsymbol{K}_{s}$ は次のように 定式化されている。

$$
\boldsymbol{K}_{S}=\boldsymbol{K} \boldsymbol{S}^{T}\left(\boldsymbol{S} \boldsymbol{S}^{T}\right)^{-1} \boldsymbol{S}
$$

すなわち $\mathrm{LQ}$ 制御におけるフィードバックダイン $\boldsymbol{K}$ を準最適フィードバックゲイン $\boldsymbol{K}_{S}$ に置き換えること により準最適フィードバックを実現することができ る.

以上で設計された制御系の全体像をブロック線図で 表すと図6のようになる。

\section{4. 制御効果の解析}

以上で設訃された制御系によりシミュレーションを 行う。重み係数行列 $Q, R$ は次のものを用いる.

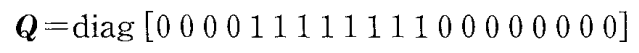$$
\boldsymbol{R}=\operatorname{diag}\left[1 \times 10^{-3} 1 \times 10^{-3}\right]
$$

フィルタは二次のローパスフィルタを使用し,パラ メータはカットオフ周波数 $100 \mathrm{~Hz}$, 減衰比 0.6 とす る.このときの各構造物の周波数応答を図 7 に示す。 ただし，細い実線は非制御時，太い実線は制御時の忘 答である。図 7 より, 制御を掛けることにより各構造 物の一次から四次の共振ピークが抑制されており，制

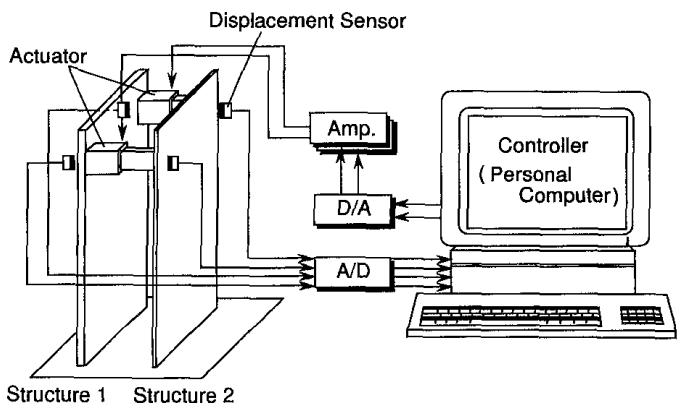

Fig. 9 Experimental setup

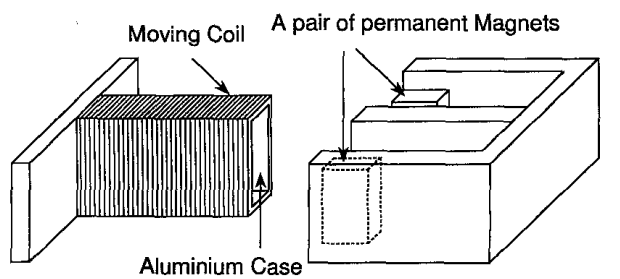

Fig. 10 Construction of actuator 


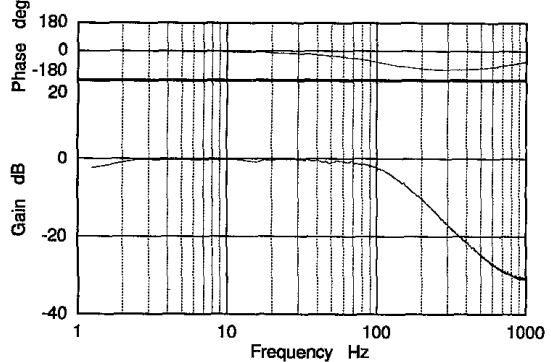

Fig. 11 Frequency characteristics of low pass filter

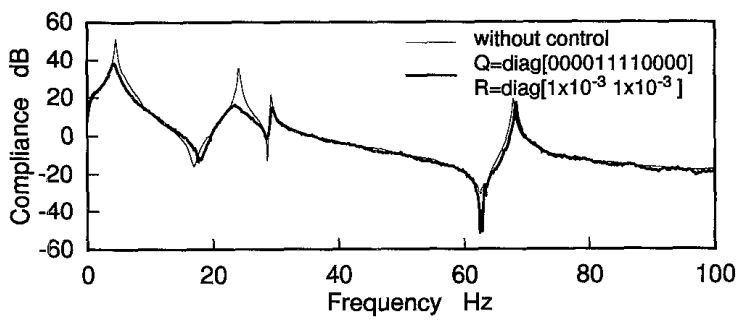

(a) Structure 1

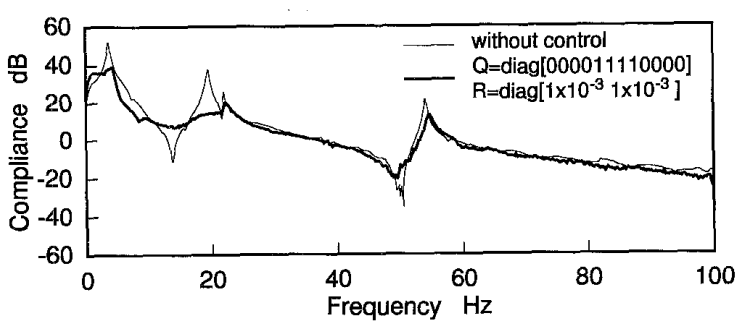

(b) Structure 2

Fig. 12 Measured frequency response

御の効果が現れている.

次に各構造物のインパルス入力に対する時刻歴応答 を図 8 に示す．図 7 と同様に, 細い実線は非制御時, 太い実線は制御時の応答を示している。図 8 より，お の扮のの構造物の各質点に括いて一次から四次の振動 が速やかに収束していることがわかる。

\section{5. 振動制 御 実 験}

$5 \cdot 1$ 実験装置の構成 四 9 に実験装置の構成を 示す．実験装置は図 9 のように, 制御対象の並列構造 物,アクチュエータ, 変位センサ, $\mathrm{A} / \mathrm{D} \cdot \mathrm{D} / \mathrm{A}$ 変換器, パーソナルコンピュータから構成されている。また， アクチュエータは永久磁石とコイルからなる非接触の 電磁式であり，同時に渦電流損失により減衰力を得る ハイブリッド方式の構造になっている(図 10 参照).

各構造物の絶対変位を変位センサにより観測して, $\mathrm{A} / \mathrm{D}$ 変換器を介してコンピュータに入力する.コン ピュータ内では，入力された装位信号から差分により 速度信号を求めて，シミュレーションにより決定した フィードバックゲインを用いて制御量を算出する。さ

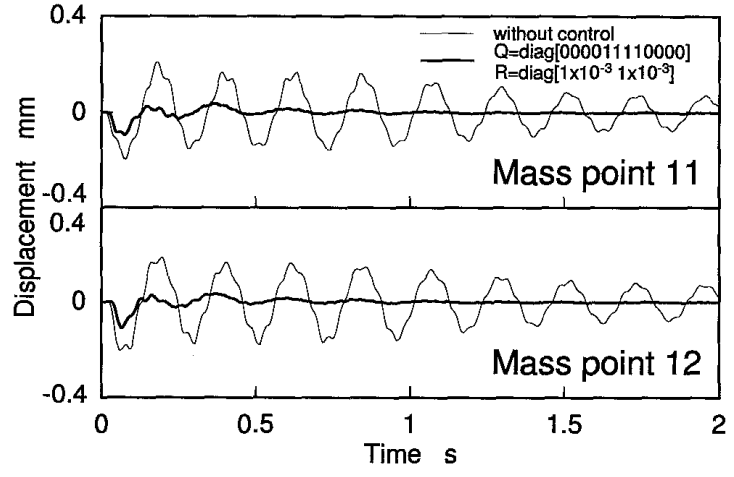

(a) Structure 1

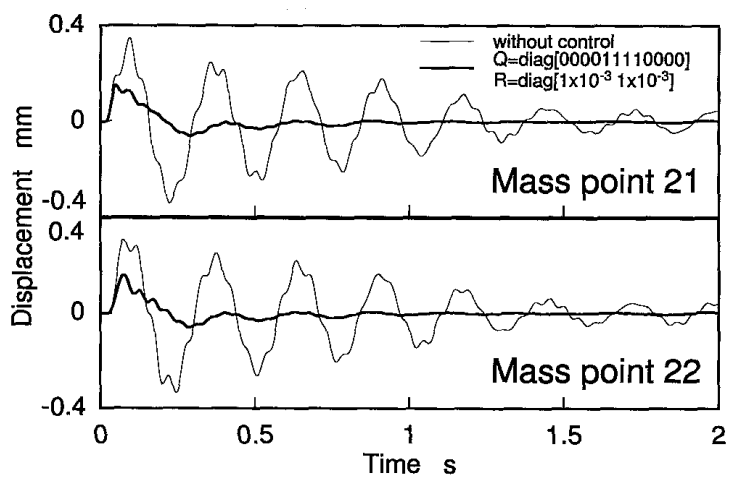

(b) Structure 2

Fig. 13 Measured impulse response

らにソフトウェアフィルタにより高周波成分の感度を 低滅して出力し,アクチュエータにより制御力に変換 されて構造物を制振する。

$5 \cdot 2$ 実験結果 次にシミュレーションに対応す る実験結果を示す。細い実線は非制御時，太い実線は シミュレーションと同じ重み係数を掛けたときの制御 時の応答である。また使用するローパスフィル夕は， 図11のような特性をもつ。

図 12 の周波数応答では，各構造物の共振ピークが 抑制されており制御の効果がみられる，ただし，構造 物 1 の四次の共振ピークがあまり下がっていない。ま た図 13 のインパルス入力に対する時間応答では，構 造物の各質点で一次から四次までの振動が速やかに収 束し，かつ制御詨象から外された五次以降の振動がス ピルオーバを起こすことなく，安定状態にあることが わかり，良好な制御効果が得られていることが確認で きる。

\section{6. 結 論}

以上，数値解析と実験結果により以下の結論を得 た.

（1）著者らが提案する「不可制御，不可観測性を 活用した低次元化モデル作成法」により，構造物の曲 
げとねじれのモードを考慮した四自由度系の低次元化 モデルを容易に作成することができ，また実機とモデ ルの周波数応答を比較することでこのモデルが物理現 象を正しく表現していることを確認し，本手法の有効 性を示した。

（2）前報でも用いた「不可制御・不可観測性を活 用した低次元化モデル作成法」と「フィル夕学包含す るLQ制御」を併用する手法に加え，「準最適制御理 論」を導入することにより，比較的簡単な制御系で本 研究のように多くの振動モードを制御する場合でも十 分制御することが可能であることを示した.

（3）著者らが提案する「ビル連結方式」が新しい 制振法の一つとして実現可能であることを実証した。

\section{文献}

（1）背戸一登, 振動のアクティブ制御，日本音響学会誌，47-9 (1991), 668-677.

（2）背戸一登・光田慎治, 不可制御・不可観測性の活用に上 る弾性構造物の低次元化物理モデル作成法と振動制御法, 機論, 57-542, C (1991), 3393-3399.

（3）背戸一登 - 土井文夫 - 井上浩男 -久谷益士郎 - 南真和, 長大橋主塔模型構造物の振動制御(第 2 報, フィル夕包含 準最適制御法とその効果)，機論, 63-609, C (1997)，14131420.

(4) Kosut, R. L., Suboptimal Control of Linear TimeInvariant Systems Subject to Control Structure Constraints, IEEE. Trans. Autom. Control, AC15-5(1970), $557-563$. 